\title{
Neonatal Sepsis, Early-Onset
}

National Cancer Institute

\section{Source}

National Cancer Institute. Neonatal Sepsis, Early-Onset. NCI Thesaurus. Code C116803.

An infectious disorder of newborn infants that is characterized by a systemic

inflammatory response within 72 hours of life and is most commonly caused by bacteria. 